Б. П. Лазоренко

\title{
ТЕХНОЛОГІЯ РЕІНТЕГРАЦІЇ ТА РЕАДАПТАЦІЇ ОСОБИСТОСТІ, ФРАГМЕНТОВАНОЇ ВНАСЛІДОК ПСИХОТРАВМАТИЗАЦІЇ
}

Фрагментацію, дисоціацію, сепарацію і відчуження визначено як провідні соціально-психологічні механізми психотравматизації особистості. 3'ясовано, що механізм парадоксальної реакції актуалізує спонтанно-конструктивні процеси реструктуризації конфліктних зв'язків, реінтеграції особистості шляхом залучення соціально-психологічних ресурсів у нову цілісність і іiі стабілізації завдяки відповідним типам практик. Повагу, довіру та спонтанність розкрито як основні технологічні принципи реінтеграції та реадаптації. Присвоєння визначено як протилежний щодо відчуження механізм, який реалізується завдяки зворотному перетворенню наміру та дії механізму парадоксальної реакції. Виокремлено основні етапи алгоритму реалізації реінтеграції та реадаптації проблемної особистості. У пілотному емпіричному дослідженні визначено типові негативні, позитивні і нейтральні психоемоційні та психосоматичні стани. До негативних психоемоційних станів віднесено застережні стани страху, тривоги, втоми та стани розгубленості, розпачу, туги, ненависті, образи, вини тощо, до позитивних - перехідні стани легкості, спокою, радості, а також фінальні інтегральні стани умиротворення, любові, упевненості, свободи, вдячності, які визначено як критеріальні щодо завершення спонтанно-конструктивного процесу переживання наслідків травматичних подій.

Ключові слова: особистість, психотравматизація, спонтанноконструктивні процеси, реінтеграція, реадаптація.

Проблема. Унаслідок воєнних дій на сході країни, що не припиняються уже три роки, усе більшого поширення набуває явище первинної i, унаслідок впливу травмованих осіб на своє оточення, вторинної психотравматизації. У зв'язку із цим постає необхідність вдосконалення технологій реінтеграції та реадаптації особистості, що зазнала психотравматизації. Дослідженню цієї проблеми присвячено велику кількість літератури. Автори розглядають різні аспекти даної теми - психологічні, психотерапевтичні, соціальні, соціальнопсихологічні, медико-соціальні, медико-психологічні та інші. Дуже важливо, на наш погляд, звернути увагу на подальше розроблення соціально-психологічного аспекту означеної проблеми - i, перш за все, на з'ясування механізмів психотравматизації особистості та засобів відновлення іï цілісності й ефективності функціонування. 
Відомо, що значна кількість людей, які дістали ті чи інші психотравми, не вважають за потрібне звертатися по допомогу, хоча це значною мірою могло б покращити як їхнє психологічне благополуччя, так і самопочуття їхніх близьких. В Україні ж у ситуації гібридної війни 3 її тривожною невизначеністю чимало людей схильні наразі необгрунтовано загострювати увагу на своїх некомфортних психоемоційних станах. У цьому контексті проблема поширення психотравматизації населення набуває неабиякого соціальнопсихологічного значення, оскільки значна кількість людей потребує відповідної соціально-психологічної корекції та підтримки з тим, щоб покращити свій власний стан і менше турбувати своїх рідних і близьких. На наш погляд, для розв'язання цієї проблеми потрібно вдосконалювати надання психологічної та психокорекційної допомоги особам, які їі потребують, з одного боку, та поліпшувати організацію соціально-психологічної підтримки і супроводу таких осіб та їхніх близьких 3 другого. Це потребує розроблення нових засобів надання такої допомоги, а також оптимізації та підвищення ефективності вже наявних.

Мета статті: висвітлення результатів застосування авторської технології реінтеграції, стабілізації та соціальної реадаптації особистості, фрагментованої внаслідок психотравматизації.

Зазвичай у визначеннях психологічної травми акцент роблять на iii медико-психологічному аспекті, що зумовлено загальним впливом медичної парадигми на розуміння концепту травми. Зокрема, в українській Вікіпедії іï визначають як психічний розлад; шкоду, завдану психічному здоров'ю людини в результаті інтенсивного впливу несприятливих факторів середовища або гостроемоційних, стресових впливів [1]. Аналогічне визначення пропонується і в англійській, і в російській версіях. Провідним смислотворчим концептом у такому визначенні $є$ стресовий розлад. На жаль, досі немає визначення власне психотравми особистості. Разом з тим у психотерапевтичних і психіатричних дослідженнях широко представлені визначення різних форм травматизації особистості, які концептуалізуються в понятті розладів особистості. При цьому за причини цих розладів визнаються конституціонально-генетичні (зумовлені фізичними і психічними травмами) i соціально-психологічні чинники. У контексті нашого дослідження такими причинами $є$ переживання людиною психічного, фізичного i сексуального насилля внаслідок безпосередньої або ж опосередкованої причетності до воєнних дій, що й спричинює психотравматизацію особистості, розлади iï психологічного і соціального функціонування. Тобто психотравматизація людини як особистості полягає в розладах їі психологічного (передусім психоемоційного і психосоматичного) i 
соціального функціонування, у їі нездатності регулювати свої стани, керувати своєю поведінкою і стосунками з близьким та навколишнім соціальним оточенням, що зумовлено зовнішніми природними і зокрема соціальними чинниками.

Результати наших досліджень дають підстави стверджувати, що психотравматизація актуалізує механізми фрагментації, розщеплення особистості на окремі субособистості, їх подальшу дисоціацію, сепарацію і відчуження найбільш дошкульних субособистостей та поєднання ї у складну систему співзалежних, конкурентних зв'язків, у тому числі конфліктних. Наслідком і виявом психотравми в ії̈ соціально-психологічному аспекті є формування дисгармонійних та дисфункціональних міжсубособистісних стосунків у вигляді різних форм дисонансу - когнітивного, емоційного, мотиваційного, смислового, переконань. У розвинутих формах цей дисонанс набуває формату внутрішньоособистісних конфліктів співзалежних субособистостей.

Сутність процесу фрагментації розкривають структурна модель особистості Е. Берна (дорослий, дитина, батьківська фігура); субособистісна модель Р. Ассаджіолі; феномен “множинної особистості" дисоціативний розлад ідентичності; констеляційні моделі М. Кібеда, I. Лаора, Б. Геллінгера та ін. Хоч фрагментація, дисоціація, сепарація і відчуження $\epsilon$ механізмами власне психотравматизації, однак вони частково можуть виконувати і позитивну функцію - збереження важливого травматичного змісту в субособистісній формі задля уможливлення подальших конструктивних процесів його реструктуризації, реінтеграції і стабілізації в новій цілісній, реінтегрованій особистості з подальшою іiі реадаптацією до реального суспільства. Задіяння згаданих конструктивних процесів набуття особистісної цілісності - реструктуризації, реінтеграції і стабілізації - може відбуватися спонтанно, часто - завдяки залученню внутрішніх і зовнішніх ресурсів особи. Проте таке трапляється не завжди. Труднощі, невдачі у відновленні цілісності якраз і зумовлюють феномен психологічної травми й посттравматичні розлади особистості в їх соціально-психологічному вимірі.

Щоб допомогти актуалізувати ці конструктивні процеси та забезпечити їх супровід в реінтеграції психотравмованої особистості, ми розробили авторську технологію, яка є важливою складовою відповідного реабілітаційного комплексу [2; 3]. Як показує наш досвід, кожна особа, що переживає наслідки психотравматизації, проходить через процес фрагментації на співзалежні субособистості. Вони звичайно $\epsilon$ носіями певних сімейно-родових програм і практик - як конструктивних, так і деструктивних. Надання психологічної допомоги щодо реінтеграції особистості передбачає створення умов для пошуку i віднайдення серед програм певних субособистостей таких, які допома- 
гають відновленню повноцінного, цілісного функціонування особистості або ж, навпаки, заважають цьому.

Кожна із субособистостей є суб' єктним утворенням, “тягне ковдру на себе", намагається стати і бути лідером щодо субординації і координації інших субособистостей. Такий стан описується у відомій байці Крилова “Квартет”, у байці Глібова про Лебедя, Щуку і Рака. Людина переживає конфлікт самої себе із собою, вона хоче керувати своїми станами, але не в змозі це робити; вона хоче робити одне, а робить зовсім інше; іiі “вибиває” з її звичного стабільного стану, "несе” і “заносить”. Один із популярних запитів на психологічну допомогу звучить так: “допоможіть розібратися”. Насправді ж потреба полягає в тому, щоб допомогти особі знову “зібратися докупи”, але вже в нову цілісність, оскільки стара особистісна цілісність була нездатною опанувати виклики, породжені травматичними подіями.

Невдалі особистісні спроби опанувати наслідки травматичних подій зумовлюють загострення внутрішньоособистісного конфлікту. Порушується координація і свідома регуляція власної поведінки. Внутрішньоособистісний конфлікт провокує зовнішні конфлікти. Як правило, особа проекує свій стан на оточення, вважаючи його винним у своїх негараздах. Формується компенсаторне "порочне коло" суперечливих зв'язків за моделлю драматичного трикутника С. Карпмана “Жертва - Переслідувач - Рятівник”, у якому конфліктна ситуація позірно вирішується в цьому компенсаторному опосередкуванні перекладанням образи, вини і відповідальності за розв'язання суперечності на відповідні співзалежні субособистості, які беруть у конфлікті активну участь, а також на зовнішне оточення.

Існує широкий спектр технологічних засобів подолання внутрішньоособистісних конфліктів різними психологічними та психотерапевтичними способами. Найбільш близькою до нашого підходу $є$ парадоксальна психотерапія [4]. Переважна більшість зазначених способів грунтується на свідомих, раціональних засадах. Дана технологія в її соціально-психологічному вимірі залучає і використовує позаособистісні (перш за все сім'ю і родичів, друзів, товаришів по роботі, службі) та підсвідомі (образи сімейно-родової системи та колективного несвідомого - міфологічні, архетипні, символічні образи долі, родових сил, стихій тощо) ресурси.

Щоб оптимізувати розв'язання внутрішньоособистісних конфліктів, підвищити ефективність допомоги, ми спробували вдосконалити описану вище технологію. При цьому було використано досвід надання психологічної допомоги особам, які переживають внутрішньоособистісний конфлікт. 
Основними технологічними принципами забезпечення ефективності реінтеграції та реадаптації особистості, фрагментованої внаслідок психотравматизації, стали:

- поважне ставлення до особистості і її психологічних захистів;

- поважання субособистісних травматичних станів (перш за все деструктивних), сприйняття їх як “старших, великих фігур” підсвідомої сфери психіки щодо травмованої особи і відповідне ставлення до них;

- принципи суб'єктності та вчинковості за В. О. Татенком;

- принцип парадоксальності засвоєння деструктивного змісту психотравми відповідно до реалізації механізму парадоксальної реакції; станів;

- принцип спонтанності перебігу та зміни субособистісних

- принцип довіри між психологом, психотерапевтом, фасилітатором і травмованою особою.

На основі зазначених принципів розв'язуються міжсубособистісні конфлікти і реалізується внутрішня реінтеграція особистості, яка забезпечує в подальшому зовнішню її реінтеграцію з близьким родинним та зовнішнім соціальним оточенням, а також подальшу реадаптацію особи до життя в сучасному українському суспільстві.

Основні етапи алгоритму реалізації зазначеної технології такі:

- створення простору довіри у фасилітативному супроводі спонтанно-конструктивних процесів реінтеграції субособистості; налагодження довірливого контакту з особистісними захистами особи, що уможливлює доступ до її спричинених психотравматизацією фрагментованих травматичних станів;

- долучення особи до спонтанно-конструктивного процесу реінтеграції цих фрагментованих травматичних станів, уособлених у відповідних субособистостях;

- фасилітативний супровід перебігу та зміни психоемоційних і психосоматичних станів до досягнення базового інтегрального стану і зупинки процесу;

- укорінення базового інтегративного стану, його конструктивна стабілізація в способах поведінки та узвичаєння у відповідних типах практик.

Останній етап алгоритму здійснюється в три основні підетапи. Реалізація першого полягає в укоріненні базового стану в просторі уяви шляхом встановлення психоемоційних зв'язків цього стану із сімейно-родовими ресурсами особи та 3 травматичною ситуацією, яка спричинила психотравматизацію особистості. Другим підетапом $\epsilon$ укорінення та стабілізація інтегрального базового стану шляхом фор- 
мування та напрацювання способів конструктивної поведінки та практик реалізації цього стану в спілкуванні з близьким та зовнішнім соціальним оточенням. Змістом третього підетапу є подальша стабілізація напрацьованих практик та реадаптація особистості до наявних умов суспільного життя, що забезпечується створенням груп взаємодопомоги, формуванням спільноти (субкультури), зацікавленої у взаємній підтримці в рамках досягнутого способу життя. На цьому етапі реалізуються різні типи просоціальних практик. Основними серед них є: індивідуально-психологічні, які передбачають суб'єктне, відповідальне ставлення до самого себе, своєї життєдіяльності і їі результатів; соціально-психологічні, що зумовлюють просоціальну взаємодію особистості з близьким і зовнішнім соціальним оточенням, та духовнопсихологічні, які реалізують цінності поваги, довіри, доброчинності, миролюбності, надійності, справедливості тощо у ставленні до себе i свого оточення.

3 погляду забезпечення ефективності технології ми виокремили такі спонтанно-конструктивні процеси:

- реструктуризація зумовлених фрагментацією, дисоціацією та виосібненням суперечливих міжсубособистісних зв'язків;

- реінтеграція дисоційованих субособистостей у нову цілісну особистість;

- усталення досягнутої цілісності в способах поведінки, відповідних типах практик та просоціальному способі життя;

- реадаптація оновленої особистості шляхом узвичаєння власних соціально-психологічних практик відповідно до чинних вимог, норм і цінностей сучасного українського суспільства.

Допоміжними засобами в забезпеченні ефективності технології $\epsilon$ адаптовані до реабілітаційного процесу тілесно зорієнтовані технології, які дають змогу підтримувати контакт і довіру між особою і психологом-фасилітатором (в індивідуальних реабілітаційних сесіях), а також іншими членами реабілітаційної групи (під час проведення групових занять). До таких засобів належать також дихальні психотехніки. Вони допомагають належним чином зосереджувати увагу на відповідних психоемоційних та психосоматичних станах і процесах, регулюють глибину та інтенсивність їх проживання, сприяють саморегуляції їх перебігу.

3 огляду на основні завдання реінтеграції та реадаптації особистості визначено провідні функиії даної технології:

- виявлення головних субособистостей і притаманних їм фрагментів, фігур, станів, їхніх рольових характеристик - провідних способів дії;

- 3'ясування субособистісних станів і сприяння динаміці їх змін; 
- досягнення й утримання базового інтегрального стану, налагодження позитивного зв'язку цього стану як з важливими фігурами сімейно-родової системи в просторі минулого і сучасності, так і з травматичною ситуацією;

- сприяння формуванню нових практик особистісного життєконстуювання різного типу - індивідуально-психологічних, соціальнопсихологічних та духовно-психологічних;

- забезпечення реалізації конструктивних процесів внутрішньої реструктуризації і реінтеграції особистості, а також зовнішньої іiі реадаптації та реінтеграції в сучасне українське суспільство.

Процес зцілення не є прямолінійним й одноразовим. Його перебіг може ускладнюватися рецидивами повернення до попередніх травматичних психологічних реакцій і стереотипів поведінки. У таких випадках доцільним $є$ прийняття та переживання повторних травматичних станів та їх чинників відповідно до цієї технології. В опрацюванні рецидиву може певною мірою допомогти модель зміни залежної поведінки J. O. Prochaska, C. C. DiClemente, J. C. Norcross [5].

Цікавими видаються результати проведеного нами пілотного емпіричного дослідження особливостей реінтеграції (за даною технологією) особистості, фрагментованої внаслідок психотравматизації. Вибірка досліджуваних становила 35 осіб віком від 21 до 46 років, 3 них 21 жінка і 14 чоловіків. Серед респондентів були учасники АТО, волонтери, пересічні громадяни. Основні їхні запити - подолання наслідків психотравматизації та поточних травматичних впливів щодо себе, а також допомога близьким, членам родини: “позбутись...”, “досягти..., здобути... і стати...”, "розібратись...”, “вплинути і змінити... (себе чи когось)".

Визначено найбільш поширені психоемоційні стани респондентів, які сприймаються ними як негативні, позитивні і відносно нейтральні. Серед психоемоційних станів, що сприймаються досліджуваними негативно, виокремлено два типи: перший - це застережні стани страху, тривоги, втоми; другий - стани розгубленості, розпачу, печалі, туги, нервозності, роздратування, гніву, ненависті, образи, вини. Серед психоемоційних станів, що оцінюються досліджуваними позитивно, визначено два основних типи: перший - перехідні стани легкості, спокою, радості тощо, які змінюються і чергуються з іншими станами в процесі спонтанно-конструктивного їх проживання; другий - це фінальні інтегральні стани, які завершують процес трансформації негативних станів у позитивні (своєрідним критерієм його повноти є здатність особи засвідчити, що вона перебуває в певному стані, а не просто відчуває цей стан у собі). 
Виокремлено три групи найбільш поширених психосоматичних станів респондентів: такі, які сприймаються ними як негативні, позитивні і фоново нейтральні. До негативних психосоматичних станів можна віднести біль, тиск, тремор, холод, жар, скруту, падіння, пітливість та ін. Серед психосоматичних станів, що сприймаються досліджуваними позитивно, - тепло, легкість, відчуття польоту, розслабленість, сонливість тощо. Також виокремлено відносно нейтральні психоемоційні стани, такі як порожнеча, безвихідь, ступор, прострація, байдужість та ін.

3'ясовано критеріальні стани завершення спонтанноконструктивного процесу та психоемоційної інтеграції особистості, що переживає наслідки травматичних подій. Це умиротворення, любов, упевненість, свобода, вдячність.

Що ж до вдосконалення і підвищення ефективності технології, то зазначено доцільність фокусування психологом-фасилітатором уваги на не усвідомлюваних досліджуваними фонових станах (як правило, обернених, протилежних щодо проявлених), і подальшого їх сприйняття з увагою, повагою і вдячністю.

Висновки. Розкрито соціально-психологічний аспект психотравматизації особистості. Визначено, що механізми фрагментації, дисоціації і виосібнення зумовлюють формування окремих субособистостей і конфліктність їхньої взаємодії. Внутрішньоособистісні конфлікти провокують зовнішні конфлікти з близьким сімейним і зовнішнім соціальним оточенням.

Удосконалено технологію реінтеграції травмованої особистості. Показано, що механізм парадоксальної реакції актуалізує спонтанноконструктивні процеси реструктуризації конфліктних зв'язків, реконструкції і засвоєння деструктивного психотравматичного досвіду, реінтеграції особистості шляхом залучення соціально-психологічних ресурсів у нову цілісність і ії стабілізації завдяки відповідним типам практик.

Визначено основні технологічні принципи забезпечення ефективності перебігу спонтанно-конструктивних процесів, серед яких провідними $\epsilon$ принципи поваги, довіри та спонтанності. Виокремлено основні етапи алгоритму реалізації зазначених технології. Наголошено на важливості останнього, третього, етапу, під час якого здійснюється соціально-психологічне укорінення та стабілізація особистісної цілісності, а також реадаптація особистості в соціумі завдяки узвичаєнню відповідних індивідуально-, соціально- і духовно-психологічних практик.

У ході пілотного емпіричного дослідження визначено типові негативні, позитивні та нейтральні психоемоційні та психосоматичні 
стани. Описано інтегральні стани, які означено як критеріальні щодо завершення спонтанно-конструктивного процесу переживання наслідків травматичних подій; до них віднесено умиротворення, любов, упевненість, свободу, вдячність.

\section{Лimepamypa}

1. Психологічна травма [Електронний ресурс]. - Режим доступу : https://uk.wikipedia.org/wiki/Психологічна_травма.

2. Лазоренко Б. П. Реабілітаційний комплекс надання психологічної допомоги та соціально-психологічного супроводу учасників АТО, що зазнали психотравми та ПТСР / Б. П. Лазоренко // Актуальні проблеми психологічної допомоги, соціальної та медико-психологічної реабілітації учасників антитерористичної операції : матеріали наук.-практ. конф. (м. Київ, 3 червня 2015 р.) / Міністерство оборони ; Нац. У-т оборони України ім. Івана Черняховського. - К., 2005. - С. 190-192.

3. Лазоренко Б. П. Психотравма як ресурс соціально-психологічної реабілітації проблемної молоді, яка переживає наслідки повоєнної психотравматизації / Б. П. Лазоренко // Актуальні проблеми соціології, психології, педагогіки : зб. наук. статей / Київ. нац. ун-т ім. Тараса Шевченка. - К. 2015. - № 4 (29). - С. 110-115.

4. Уикс Дж. Р. Психотехника парадокса. Практическое руководство по использованию парадоксов в психотерапиии / Дж. Р. Уикс, Лучиано Л'Абат. - М. : Маркетинг, 2002. - 278 с.

5. Prochaska J. O. In search of how people change. Applications to Addictive Behaviors / J. O. Prochaska, C. C. DiClemente, J. C. Norcross // American Psychologist. - 1992. - Is. 47. - P. 1102-1104.

\section{References}

1. Psykholohichna travma [Psychological trauma], https://uk.wikipedia.org/wiki/Psykholohichna travma [downloaded 23 February] (ukr).

2. Lazorenko, B. P. (2005). Reabilitatsiinyi kompleks nadannia psykholohichnoi dopomohy ta sotsialno-psykholohichnoho suprovodu uchasnykiv ATO, shcho zaznaly psykhotravmy ta PTSR [Rehabilitation complex of psychological assistance and social and psychological support of ATO participants who have got psychotrauma and PTSD]. Aktualni problemy psykholohichnoi dopomohy, sotsialnoi ta medyko-psykholohichnoi reabilitatsii uchasnykiv antyterorystychnoi operatsii: Materialy naukovo-praktychnoi konferentsii (Kyiv, 3 chervnia 2015 r.) [Actual problems of psychological assistance, social and medical-psychological rehabilitation of participants in the antiterrorist operation: Materials of the scientific-practical conference (Kyiv, June 3)] (pp. 190-192) (ukr).

3. Lazorenko, B. P. (2015). Psykhotravma yak resurs sotsialno-psykholohichnoi reabilitatsii problemnoi molodi, yaka perezhyvaie naslidky povoiennoi prsykhotravmatyzatsii [Psychotrauma as a resource of social and psychological rehabilitation of problem youth which experience the consequences of postwar 
traumatization]. Aktualni problemy sotsiolohii, psykholohii, pedahohiky [Actual problems of sociology, psychology, pedagogy], 4 (29), 110-115 (ukr).

4. Gerald, R. Weeks, Luciano L'Abat (2002). Psikhotekhnika paradoksa. Prakticheskoye rukovodstvo po ispolzovaniyu paradoksov $v$ psikhoterapii [Psychotechnique of paradox. A practical guide for using of paradoxes in psychotherapy]. Moscow: Marketing Publ. (rus).

5. Prochaska, J. O., DiClemente, C. C. and Norcross, J. C. (1992). In search of how people change. Applications to Addictive Behaviors. American Psychologist,

47, 1102-1104.

\section{Lazorenko B. P. Technology of reintegration and readaptation personality fragmented by psychological trauma}

Fragmentation, dissociation, separation and alienation are defined as the min social and psychological mechanisms of psychotraumatisation of personality. It is found out that the mechanism of paradoxical reaction actualizes spontaneous and constructive processes of restructuring of conflict connections, reintegration of personality by involving social and psychological resources into a new integrity and stabilizing it due to the appropriate types of practices. Respect, trust and spontaneity are disclosed as the main technological principles of reintegration and re-adaptation. Assignment is defined as an opposite to the alienation mechanism, which is realized through the reverse transformation of intent and the action of the mechanism of paradoxical reaction. The main stages of the algorithm of implementation of reintegration and re-adaptation of the problem person are outlined. The typical negative, positive and neutral psycho-emotional and psychosomatic states are identified in the previous empirical study. The negative psycho-emotional states include precautionary states of fear, anxiety, fatigue and states of confusion, despair, anguish, hatred, offenses, fault, etc. The positive ones are transitional states of lightness, tranquility, joy, as well as final integral states of pacification, love, confidence, freedom, gratefulness which is defined as a criterion for the completion of the spontaneously constructive process of experiencing the consequences of traumatic events.

Key words: personality, psychotraumatisation, spontaneous-constructive processes, reintegration, readaptation.

(С Лазоренко Б. П. 